\title{
Paths to peace for NATO's partnerships in Eurasia
}

\author{
Joshua B. Spero
}

This chapter examines the role of multilateral cooperative efforts and institutionalised security cooperation in the Eurasian area through a study of NATO's PfP programme. In terms of measuring the capacity to increase Eurasian security, the general track record of the post-Cold War security institutions in non-traditional areas of societal democratisation, economic modernisation, civil and cross-border war prevention, and Eurasian integration presents a mixed picture. ${ }^{1}$ By focusing on the Eurasian politico-military partnerships created with NATO, it is possible to gain an understanding of how targeted policies supported by multilateral institutions can increase security in the Eurasian area. NATO's PfP provides a myriad of programmes between NATO and non-NATO states utilising multilateral military cooperation to educate, train, exercise, and allow military staff and civilian officials to operate effectively together. ${ }^{2}$ Since its January 1994 inception, the PfP has created substantial security enhancements in Eurasia and contributed directly to the capacity of allied nations to deploy troops to the region in the post-September 11 anti-terrorist coalition.

The PfP has evolved into an exemplary model of institutionalised civilmilitary cooperation among over forty European and Eurasian states. The success of the PfP has had an important impact feeding back into NATO, thus facilitating NATO's own post-Cold War survival. None the less, the future of PfP will depend heavily on whether NATO can adapt adequately to the kinds of post-September 11 threats confronting both allies and partners. By incorporating the experiences of the PfP into NATO planning, the alliance may be in a stronger position to adapt to current and future challenges. ${ }^{3}$ Almost six years of PfP cooperative planning and operations in Eurasia have laid part of the foundation to counter such non-traditional threats as terrorism, the proliferation of WMD, ethnic conflict, resource depletion and narcotics trafficking in Eurasia. The PfP provides the principal mechanism through which NATO cooperates with individual and regional groupings of 
non-NATO nations. These cooperative mechanisms focus on long-term training regimens and have integrated the Eurasian participants into NATO planning facilities at NATO headquarters in Belgium and at all NATO military commands. This chapter concentrates on several aspects of the PfP's contribution to Eurasian security.

\section{The origins of the PfP}

During the early to mid-1990s a handful of key American officials, in the Departments of Defense and State, developed the PfP concept. PfP was born in 1993, largely from concepts developed by Joseph Kruzel, deputy assistant secretary of defence for Europe and NATO, and General John Shalikashvili, chairman of the joint chiefs of staff, who had served previously as NATO supreme allied commander of Europe. Though the initial demand for PfP reflected a desire to provide a short-term alternative to expanding NATO's membership, the concept eventually evolved so that it truly changed early post-Cold War thinking about multilateral European security cooperation. At its core, the PfP is premised on a belief that the more civilian strategists and military operators plan together within an integrated civil-military command structure like NATO, the greater the likelihood of peaceful international relations. Moreover, by introducing states to western models of civil-military relations, NATO might help to stabilise weak post-Soviet states throughout eastern Europe and Eurasia - even those states that would not eventually seek NATO membership. Such a design required significant building-block initiatives to proceed in earnest and develop institutionally. NATO represented the ideal institution through which to promote this goal because of its multilateral and cooperative focus on shared politico-military approaches, norms, standards and operating procedures developed over decades of multilateral cooperation.

American strategic planners, mainly in the Pentagon, however, needed to ensure that PfP first survived its early tests. Such challenges included American initiatives to pursue long-term linkages and then enhanced relationships through NATO institutionally with the unstable states in the Caucasus and Central Asia - frequently seen by NATO's European allies, except Turkey, as outside the area of European security. Senior US officials, reinforced with crucial staff initiatives (mostly emanating from the joint chiefs of staff), made this happen during the administration of President William J. Clinton. ${ }^{4}$ Each participant in the interagency debate had different reasons for backing the PfP, with some seeing it as a means of deferring debate over expanding NATO membership and others seeing it as facilitating NATO's expansion over time. Either way, had this coalition of key senior US policy-makers not thrown its support and leadership behind the Kruzel-Shalikashvili initiative, the PfP process, without American leadership, would probably have floundered within NATO. ${ }^{5}$ 
US and NATO allies projected PfP as a non-threatening security strategy across Europe and Eurasia during the 1990s. Indeed, the PfP process evolved to become a force multiplier strategy eventually serving the interests of stability throughout the region. Through PfP, NATO and PfP nations could project their forces collectively to confront traditional and non-traditional security threats, as was demonstrated by their crucial role in providing a baseline for successful engagements in the Balkans and Afghanistan. ${ }^{6}$ The PfP initiative became one of the most important tools for the US national security strategy of engagement and enlargement to promote multilateral dialogue, planning and operating mechanisms for cooperative security. Significantly, as the PfP process progressed during the latter part of the 1990s, particularly in Georgia, Azerbaijan, Kazakhstan, Kyrgyzstan, Uzbekistan and Tajikistan, joint efforts to reduce consistent problems posed by non-state actors arose from PfP multilateral regional cooperative security that promoted, for example, counter-terrorist education, training and planning among Eurasian PfP members. ${ }^{7}$

Establishing durable procedures and processes for PfP initially presented a major challenge to NATO planners. By working with key allies such as Great Britain, Germany, Norway, Denmark, the Netherlands, Italy, Greece and Turkey, and critical PfP partners such as Poland, Ukraine, Finland, Sweden, Albania, Georgia, Kazakhstan, Kyrgyzstan and Uzbekistan, America led the shaping of PfP. Washington gave early impetus to galvanise PfP with congressionally appropriated funding, titled the Warsaw Initiative. By working closely on multilateral policy recommendations at NATO headquarters and throughout the NATO military command structure, the USallied strategy stemmed from the belief that through multilateral leadership Eurasian security could be enhanced. Even with this political dynamism, American civil-military planners knew instinctively that the military held the quickest, most pragmatic capabilities to reinforce the early, nascent and fragile PfP process in every region involved, including the Caucasus and Central Eurasia. Crucial US congressional staff members on the Senate Armed Services Committee and the Senate Foreign Relations Committee convinced members of Congress to allocate Warsaw Initiative funding to the joint chiefs of staff in late 1994 to initiate the PfP process.

The first Warsaw Initiative instalment of $\$ 30$ million allowed US joint chiefs of staff planners to formulate and recommend a broad multilateral vision of PfP to General Shalikashvili, coordinating closely with Kruzel and his European, Eurasian and NATO staffs in the Office of the Secretary of Defense. To achieve such a vision, General John Shalikashvili, in turn, forged a dynamic political and military strategy with his strategic plans and policy staff who covered NATO and Eurasia. As chairman of the joint chiefs of staff, Shalikashvili gained support from US and NATO European and Atlantic commanders and built a strong consensus in support of PfP with the secretary of defence, William Perry, and the secretary of state, Warren 
Christopher. That consensus was then taken by the national security advisor, Anthony Lake, to President Clinton with the necessary game plan to implement PfP. President Clinton, in turn, was able to persuade NATO allies and PfP participants alike of the intrinsic value of this programme.

Long-term civil-military exercise programmes across Europe and Eurasia were soon developed through the PfP. These often involved thousands of civilian planners and troops conducting training events and deployments several months long. In addition to formal PfP activity, US and other NATO members conducted hundreds of bilateral and multilateral 'in-the-spirit-of PfP' programmes. As initially conceived by the US joint chiefs of staff and the Office of the Secretary of Defense, many 'in-the-spirit-of-PfP' programmes evolved into formal NATO activities. These institutional mechanisms for NATO's PfP process drew, along with important allied and partner contributions, considerably on American resources, financial support, and equipment leases or purchases to the majority of PfP nations. Consequently, US Warsaw Initiative funding, increased in subsequent years, gave PfP states important financial breathing space. Within the constraints of limited PfP nation budgets, often consumed by personnel and pension costs, American and NATO strategists pushed PfP states to modernise their militaries as best they could, while also maintaining or increasing their training and readiness. These were crucial steps for any serious effort to meet the multiple postCold War security challenges in Eurasia. As a result of this vision being taken from theory into practice, the PfP process accelerated and solidified throughout NATO's political and military committees and command structures while also taking root in many allied and PfP nations' national planning structures. As a result, PfP emerged as perhaps the most significant operational bridge between Europe and Eurasia. ${ }^{8}$

\section{Bandwagoning towards PfP}

While it is clear why PfP was so appealing to the NATO members, a key question remains: why was this particular form of multilateral cooperation so successful among the participating countries of Eurasia? International relations theory, especially that which assesses the dynamics of bandwagoning and balancing behaviour among states, helps to a considerable degree in answering this question - and also in explaining the sources of regional stability in post-Cold War Eurasia. As Randall Schweller explains, bandwagoning portrays actions that states conduct to gain reward and profit from aligning with the stronger side, while balancing characterises efforts that states take to align with the weaker in order to achieve the security of the state. ${ }^{9}$ The results from balancing, however, frequently entail more costs to states because such alignment involves balancing with a state or coalition vigorously against a strong predatory state or coalition. This balancing, whether offensively or defensively, by a state or coalition against an external 
threat perceived as serious aims to preserve and protect the state. ${ }^{10}$ As Glenn Snyder also maintains, 'the choice between conciliation and balancing involves optimising among security, autonomy, and intrinsic values: conciliation buys security at some cost to intrinsic values; balancing buys it at the cost of autonomy'. ${ }^{11}$ Moreover, antagonistic or aggressive alignment often comes at a higher cost than cooperative or conciliatory alignment. Securityseeking states can reduce the potential for conflict by revealing benign motivations, demonstrating foreign policy transparency, and signalling reassurance to decrease the risks of misperception leading to conflict, therefore avoiding spiralling tensions that can lead to a regional security dilemma. ${ }^{12}$ This defensive concept of cooperative alignment might describe state alignment more accurately, as states are choosing multilateral forms of enhancing their perceived security interests. ${ }^{13}$ This approach generally provides the best conceptual framework for understanding why Eurasian states have chosen to align with NATO through the PfP.

By choosing a strategy with the least costly alignment policy, a state decides on its balance of interest. If, as Schweller states, the objective of bandwagoning centres on the opportunity for a state to gain by joining the security system it values, the state determines that its cost to achieve security defensively might be lower than to defend the existing order, which may be more unfavourable. The security system comprises a stronger state or coalition of stronger states and the bandwagoning state attempts to align, usually during a time of geopolitical change, and not in a manner threatening to other states - especially those states outside existing security institutions. Building on Schweller's bandwagoning definition, Mark Kramer offers what he characterises as non-predatory bandwagoning alignment. States ally with others not solely because of the external security and stability sought, but also because of the expectation of distributive gains for many of the states involved. ${ }^{14}$ Kramer's concept of 'non-military' state alignment or non-predatory bandwagoning provides insights as to how the PfP led both NATO and its participants towards multilateral cooperative security strategies. Non-predatory bandwagoning states, as those joining the PfP, generally try to attain gains not through aggression, but from extending the bandwagoning state's value system. Encouraged by NATO, PfP states have sought to institutionalise the values of cooperative security even if they do not actually seek formal NATO membership.

By becoming more 'western' in their geopolitical orientation, PfP countries hope to achieve a variety of distributive gains resulting from the positive-sum experiences of non-predatory bandwagoning. PfP participants have chosen a particular form of cooperative security behaviour as an alternative to behaviour motivated by power and threat - which can lead to aggression and war. Within this conceptual framework, the motivations behind the general Eurasian trend towards PfP can best be understood. Seen as the most threatening entity by the majority of current PfP members 
during the Cold War, a post-Cold War NATO provided the non-predatory bandwagoning states with a practical path for adapting their predominantly non-threatening foreign policy and military postures, while also signalling to the international community the depth of their own state identity choices, as in the post-Soviet geopolitical space. Consequently, aggressive interstate behaviour in historically war-torn Eurasia has not emerged among PfP members.

Despite these historical achievements, there are some negative assessments of the NATO/PfP outreach process in Eurasia. A primary criticism views the PfP as a means of delaying NATO's promise to maintain an open door for absorbing new members - with the collective defence security guarantee accompanying membership. Additionally, some critics saw the PfP as not providing enough of a comprehensive strategy for ensuring the security of the signatory states. Another critique centres on the risks of overextending NATO member resources in outreach ventures to non-member PfP countries - thus diluting NATO's traditional core mission of collective defence. An additional concern reasons that overextending already resource-strapped militaries emerging from the former Warsaw Pact and post-Soviet states only undermines their prospects for democratisation. Finally, PfP advocates, both in NATO countries and in the participating non-NATO states, have generally seen the programme as receiving inadequate resource investment for it to succeed. Despite these criticisms, PfP has been the principal means for organising effective multilateral military coordination that both broadens and refines NATO's new missions and serves as the centre of geopolitical gravity for the interested post-Communist countries of Eurasia. ${ }^{15}$

Cooperation between NATO and non-NATO nations, even nations that contributed troops outside the PfP framework from Latin America, Africa, the Middle East and Asia, became important foundations of NATO's postCold War missions in operations such as Bosnia, Albania, Kosovo and the Former Yugoslav Republic of Macedonia. The PfP's consultative functions cannot solve the often ingrained domestic problems within any given PfP member-state. Rather, PfP ultimately provides a critical baseline for NATO and non-NATO nations to begin grappling effectively with twenty-firstcentury perils: WMD proliferation, international narcotics trafficking, resource depletion and environmental degradation. An important question arises in the context of these security threats: can the Eurasian countries achieve more concerted cooperation via the PfP process to overcome, or significantly reduce, such regional security challenges? Will the relatively short history of the PfP process lead Eurasian states towards the kind of successful historical reconciliation witnessed between former enemies such as France and Germany or Germany and Poland? ${ }^{16}$ Given the critical American role in European security within NATO's intricate structures that established the basis for Franco-German and German-Polish reconciliation, arguments might favour similar possibilities for the Caucasus and Central 
Asia, albeit taking into account Eurasia's uniqueness.

When regarded as inducing multilateral political and military cooperation, the PfP promotes an enhanced capacity for states to align with NATO as a means to avoid historic great power struggles. Such interstate behaviour may help generate western ideas and state identities based on the norms and standards defined by NATO as key criteria for PfP cooperation. Nevertheless, even in such ideal circumstances, anarchy still prevails in the international system, and state leaders must choose from political alignments that will first and foremost help them ensure the security of their states. None the less, as when the United States deployed forces in Eurasia during the autumn 2001 campaign in Afghanistan, its state strategies were indirectly aided by the years of multilateral cooperation gained through the PfP.

\section{PfP pragmatism: multilateral and cooperative}

How did PfP evolve to reach the stage where its mechanisms and procedures provide a supporting baseline for counter-terrorist coalition operations as in Afghanistan? The PfP processes represent a practical cooperative security framework between NATO and individual PfP states involving defence, operational and budgetary planning, military exercises and civil emergency operations. Its defensive principles and incentives for states to bandwagon politically and militarily with, but not necessarily to join, NATO make PfP both practical and realistic. Such cooperative security options presented Europe's neutral states (Austria, Finland, Ireland, Switzerland and Sweden) with creative post-Cold War policy options. These states, as well as most in the post-Soviet Caucasus region and Central Asia, continually reiterate that they do not need to join NATO. Rather, they want to strengthen PfP and not jeopardise relationships with other non-NATO states, particularly Russia. Therefore, a total of $46 \mathrm{PfP}$ countries plan and operate for crisis management and directly enhance NATO-led operations. In turn, these states also contribute significantly to NATO's post-Cold War adaptation. However, the way the US-led and non-NATO coalition against international terrorism develops in Eurasia will amount to a test of the future viability of the PfP. The sustainability of the PfP will be especially tested after NATO's November 2002 enlargement. For example, as NATO enlargement supersedes PfP, there will be fewer incentives remaining to invest resources in this form of multilateralism.

Because it does not guarantee the security of its signatories, PfP challenges the traditional views of NATO as a solely collective defence institution designed to defend against a threat to its members. ${ }^{17}$ Increasingly, the operational distinction between NATO and PfP members barely exists. The blurring of the distinction, however, strengthens rather than detracts from NATO's evolution and concomitant missions. As testified to by the hundreds of PfP events annually and the numerous ties with NATO's politico-military 
command headquarters and staffs, PfP mechanisms bring together, rather than separate, Eurasian states. Such a tool provides politico-military linkages and critical consultative ties without requiring PfP members to join NATO. For example, few observers thought it would be possible in NATO's first PfP exercise, 'Cooperative Bridge', to behold German troops crossing the Polish border unobstructed for the first time since World War II. As the newly unified German military re-entered Poland in September 1994, postCold War troops peacefully exercised alongside Americans and half a dozen other NATO and new PfP nations to conduct a platoon-level peacekeeping mission. ${ }^{18}$

Within less than a decade the PfP process has developed considerably. For example, by 2001, the annual Black Sea-based NATO-led multinational exercise, 'Cooperative Partner 2001', involved 4,000 troops from 13 NATO and PfP countries, including ships, fighter aircraft and helicopters. Hosted for the first time by Georgia in June 2001, 'Cooperative Partner 2001' entailed a large-scale anti-terrorism operation to release hostages, peacekeeping operations, and disaster-relief and rescue missions. ${ }^{19}$ Consequently, the September 2001 terrorist attacks on New York and Washington, DC, only underscored the vital importance of the PfP exercise in Georgia and the Black Sea the preceding June, which tested the skills and procedures required to deal with real world crisis scenarios. From Poland to Georgia, Europe and Eurasia have experienced the evolution of a cooperative security process that provides the framework for former enemy states to train and operate together. This framework allows post-Cold War European and Eurasian states to conduct twenty-first-century missions more effectively, whether via NATO-led operations or through coalitions of the willing. In effect, PfP has helped to increase security in Eurasia by lowering the transaction costs of multilateral joint military action should states decide to act within a multilateral framework for managing regional security threats.

Eventually, PfP's practical tools went well beyond NATO's initial outreach efforts to former enemies, which initially took the form of conferences, seminars and workshops. Indeed, nearly every major development in NATO's post-Cold War transformation can be linked in some respect to the PfP initiative and evolution. NATO enlargement now proceeds with a baseline of indicators and criteria developed from PfP. The NATO relationships with Russia and Ukraine build on and use PfP's mechanisms and underlying principles. NATO's important operations in the Balkans depended upon initial training and exercises via PfP and utilised PfP's civil-military interaction between NATO and non-NATO nations to make national force planning more effective and efficient. Such exercising and organisation, within a cyclical planning-execution-evaluation process, formed the embryonic headquarters, staffs and command structures in Bosnia; enabled the procedures for dealing with the aftermath of the Albanian collapse; provided the foundation for the operations in Kosovo; and figured prominently in the NATO 
mission to the Former Yugoslav Republic of Macedonia. The PfP framework also indirectly facilitates NATO's Mediterranean Dialogue with North African (Morocco and Tunisia) and Middle Eastern states (Egypt, Israel, and Jordan). The concept underlying the PfP concept has even been raised in US policy-making circles for application to other parts of the world, even if without engaging the direct institutional structure of NATO.

Alone, the PfP cannot be adjudged as having prevented the emergence of Eurasia's multiple security dilemmas or resolved them. The PfP framework did not avert the carnage and destruction in the Balkans or stop the terrorist attacks emanating from the borders of Central Asia in Afghanistan. Moreover, PfP cannot give its members the absolute security guarantee many of them want. The crucial security contribution involves the evolution, operationalisation and institutionalisation of PfP mechanisms at NATO headquarters and within individual national planning and bureaucratic processes. By building upon the early PfP baseline of national defence and budgetary transparency that upholds the tenets of democratic control of national armed forces, NATO and PfP nations bolstered military effectiveness of multinational forces that can operate with NATO ${ }^{20}$ Such a broad, fundamental application by states working within NATO allows politicians, policy-planners and military commanders to grapple together with global trans-sovereign challenges. ${ }^{21}$

\section{Deepening PfP partnerships in Eurasia}

Eurasia is an area challenged by a variety of domestic political, economic and ethno-national security dilemmas that PfP alone cannot resolve. Moreover, PfP is unlikely to influence the direction of future challenges stemming from growing corruption, autocracy, oil and natural gas competition, great power competition between Russia, China and America, or competition between regional powers such as Iran, Turkey and Pakistan all are quite beyond the capacity of a programme like PfP to influence directly. Only the states of Eurasia themselves, working in cooperation with other key states and international institutions such as the UN, World Bank and IMF, can deal with these problems directly. ${ }^{22}$ However, NATO's ongoing PfP process can apply the successful experiences of nearly a decade of multilateral cooperative programmes within the region towards an ongoing stabilising role. NATO's planning for regional and international contingencies, such as counter-terrorist operations or WMD counter-proliferation, reflects the value of such planning, training and operational linkages developed over time. Without the PfP baseline established during the latter half of the 1990s, potential stabilisation, even future democratisation and modernisation, might not occur as effectively in Eurasia - extending as far east as Afghanistan. ${ }^{23}$

If it continues to receive significant support from the NATO countries, PfP 
can maintain the bridge of greater political and military understanding between Europe and Eurasia. PfP can remain as a directory for its Eurasian participants to follow for reducing the volatility and danger sparked by potential civil and international conflicts throughout the region. Without the consistent PfP cooperation and coordination that allow US and NATO members to survey potential military training centres and even future basing areas, regional tensions and attendant state instabilities might increase in the future. ${ }^{24}$ Yet, in the aftermath of the terrorist attacks on America, the galvanisation of the world community's opinions on counterterrorism may now generate a historic opportunity for reducing future regional security problems in Eurasia via a deepening PfP process. ${ }^{25}$

Some of PfP's prospects, however, may be constrained by the various mixed signals emitted by NATO towards Eurasia. These limitations include the criticism that no clear strategic thinking exists for NATO's efforts and that individual members such as America and Turkey often pursue goals diverging from NATO as a whole, while antagonising Russia, China and Iran. Such problems influence regional security while potentially involving some NATO members in missions that they would rather avoid. ${ }^{26}$ Although some aspects of these contentions appear accurate, there is often a tendency among some analysts to misrepresent the intent of the PfP process. NATO never intended, for example, that the PfP define a policy to oppose states such as Russia, China or Iran. Moreover, although many PfP members may never seek to join NATO, these countries can continue to forge multilateral political and military cooperation aimed at reducing regional instability and preventing future conflict. This alignment reflects non-predatory bandwagoning that PfP signatory states in Eurasia seek vis-à-vis NATO. Some Eurasian states also need reassurances that they will not, in the future, be threatened by Russia. Consequently, some PfP members will continue to use their participation as a means of signalling their relative geopolitical independence from Moscow. However, the most important gains for these states stem from their broader linkage with the West as established through the PfP - and such trends include Russia, too. Alternative regional security groupings such as GUUAM (Georgia, Ukraine, Uzbekistan, Azerbaijan and Moldova) and the SCO (Russia, China, Kazakhstan, Kyrgyzstan and Tajikistan) have not yet emerged as functional alternatives to the PfP. Indeed, tensions in Eurasia have often risen as a result of these kinds of nascent balancing institutions that run counter to the sort of bandwagoning being pursued through PfP's cooperative security architectures. Potentially, the historical balance of power notions that have driven some of the Russian or Chinese alternatives to NATO programmes may decline even further as China and Russia engage in the mutual gains of counter-terrorist cooperation with western institutions in Eurasia. Given the rapid emergence of American influence in Eurasia via the US-led international coalition to combat global terrorism, entirely new links among nearly all the region's 
states appeared more possible in 2002 than ever before. ${ }^{27}$

Developments following the September 112001 terrorist attacks indicate support for the possibility of accelerated cooperation in Eurasia. China and Russia quickly endorsed UN resolutions in support of US efforts against terrorism, as did the NATO-Russia council in Brussels. Neither country raised significant concerns when US troops were deployed in Eurasian states surrounding Afghanistan. Within the region, the US-supported Central Asian Peacekeeping Battalion ('Centrasbat') is comprised of units from Kyrgyzstan, Uzbekistan and Kazakhstan. 'Centrasbat' trains Eurasian participants in the spirit of the PfP process. These alignments serve both as a key basis for multilateral cooperation and for American power projection in the region. By monitoring the Tajik-Afghan border, 'Centrasbat' prevents elements of Tajikistan's extremist Islamic opposition, which had fled to safe havens in Afghanistan, from returning. ${ }^{28}$ The regional cooperative security arrangement among all eight Trans-Caucasus and Central Asian states against the proliferation of dangerous materials and goods is another important PfP activity that promotes multilateral cooperation in the region. ${ }^{29}$ Finally, Central Asia and the Caucasus, because of their geostrategic location, now serve as key staging grounds for operations that the international coalition initiates against terrorist networks. These deployments included American, British, Turkish, French and other forces already familiar with the territory because of their years of experiences gained through the PfP. ${ }^{30}$ Taken together, these crucial international cooperative steps, based on a new willingness to set aside seemingly intractable geopolitical differences in order to fight terrorism, delineate a larger framework expanding on PfP objectives and goals.

Such expansive PfP cooperation in Eurasia did not arise spontaneously. Since the mid-1990s, the NATO allies have methodically established and implemented numerous long-term training and education programmes, including exercise cycles and familiarisation with facilities across Eurasia. Without this preparation, the rapid insertion of NATO and PfP nation troops for operations into and out of areas in Afghanistan and the Pankisi Gorge on the border with Georgia would have been greatly slowed. The PfP process took firmer hold in Eurasia when the Americans launched a series of bilateral 'in-the-spirit-of-PfP' interoperability programmes, and when NATO coordinated the 'Combined Endeavor', 'Regional Cooperation', and 'Centrasbat' exercise series. These multiple phased programmes and exercises evolved from dozens of preparatory seminars, workshops, conferences and small-scale training projects that have annually culminated in field training, command post exercising, and command, control, communications and computer systems development.

Interoperability characterises one of the primary capabilities for PfP states to possess in order to link and operate with NATO for the range of PfP missions. The US Defense Department realised from the outset of the PfP 
process that some of its nascent bilateral programmes from the pre-PfP and post-Cold War era could be adapted to fulfil critical PfP country interoperability objectives. The American strategy of aiding PfP nations to achieve interoperability with NATO centred on three main programmes intended for all PfP nations. For the Eurasian participants in PfP, the US Warsaw Initiative still provides critical assistance towards participation in these multilateral 'in-the-spirit-of-PfP' interoperability efforts. The first key area, the Regional Airspace Initiative (RAI), focused on developing civil-military airspace regimes fully compatible and interoperable with west European civilian airspace organisations and NATO. ${ }^{31}$ Second, the PfP Information Management System (PIMS) represents a system of communications connectivity and information management using off-the-shelf hardware and software designed to link PfP nation capitals with US and NATO facilities for planning exercises, sharing information and deepening daily cooperation. Establishment of close communications between PfP and NATO not only overcomes practical problems of communications with PfP capitals, but also ensures that PfP nations feel linked in a close, cooperative relationship to NATO. PIMS remains fundamental to distance learning and emergency planning. Finally, the Defense Resource Management Studies Program (DRMS) provides country-specific exchanges concerning defence planning and force structure methodology that both sides use to guide resource management and procurement decisions. DRMS facilitates establishment of a rationalised defence management system similar to those already in use by NATO allies. This crucial NATO-related budgeting and planning approach aids civil-military restructuring, especially infrastructure requirements. All of these US programmes reach well into the Eurasian area and provide an instrumental foundation for regional cooperation and integration. ${ }^{32}$

Since most of the Eurasian signatories started their PfP programmes during the mid-1990s, the NATO nations now operating in these regions for counter-terrorist contingencies can acquire an additional operational foothold via multilateral participation in PfP processes. In the case of exercise 'Combined Endeavor', conducted under the auspices of the US, European Command (EUCOM - Stuttgart, Germany), synchronised with NATO's Supreme Allied Commander Europe (SACEUR) at Supreme Headquarters Allied Powers Europe (SHAPE), and held mainly at key US training facilities in Germany, the participants identify and document command, control, communications and computer interoperability between NATO and PfP nations' equipment to attain compatibility. This exercise now includes most of the Caucasus and Central Asian states among nearly 25 NATO and PfP nations. By broadening this training, the US Central Command (CENTCOM Tampa, Florida) worked with EUCOM and individual NATO states to start the 'Regional Cooperation' exercise series. This German-based command post and computer-assisted exercise, located at the US-run Warrior Preparation Center, concentrates on peace enforcement training for contin- 
gencies of the designated Central Asian peacekeeping battalion and Caucasus contingents. By 2000, the event involved all of the key PfP states, except Tajikistan, with observers from Mongolia, Turkey and Ukraine. Finally, CENTCOM shapes the 'Centrasbat' field training exercise to enhance the Central Asian battalion's capabilities to conduct peacekeeping operations to support either UN or NATO missions, while also advancing cooperation between and among Eurasian states and other non-NATO nations. ${ }^{33}$

Like 'Cooperative Partner', 'Cooperative Determination 2001', held in Azerbaijan in November 2001, broadened regional, multilateral cooperation. Through a sophisticated 600-person command post exercise that focused on a multinational brigade staff and mobile medical centres for helping civilians, this first-time PfP exercise in Azerbaijan involved significant crisis management contingencies. Comprised of many NATO and PfP nations, including Greece and Turkey, the US and the International Committee of the Red Cross, the exercise utilised a scenario for both peacekeeping and humanitarian operations. ${ }^{34}$ Given the success of PfP exercises in the Caucasus, there is every possibility that such exercises can be expanded throughout Eurasia and possibly extend to include Afghanistan, Pakistan and even, over time, China and Iran.

\section{Toward future NATO partnerships in Eurasia}

This chapter has addressed several issues for the PfP process and its cooperative security framework within the larger security context of Eurasia. First, PfP reflected cooperative security policies and processes, best understood within the theoretical framework of realistic and pragmatic state alignments. These alignments symbolise non-predatory bandwagoning with PfP signatories seeking close relations with the once-threatening NATO institution they opposed as part of the Warsaw Pact and former USSR during the Cold War. This broad Euro-Atlantic, European and Eurasian post-Cold War structural transformation affects the way its members have defined NATO's new missions, specifically via PfP. NATO members and PfP signatories synchronised their threat perceptions over the last half of the 1990s and formed the practical cooperative security needed to change NATO as an institution.

Second, PfP has evolved into an important international cooperative security framework since the early 1990s. The PfP mechanisms underscored the progressive and advanced international security standards and procedures required for former enemies to operate together and to confront the complexities and often violent upheavals of the twenty-first century. The PfP process serves as one counter-measure against such crucial security threats as terrorism. From the practical civil-military cooperation and coordination arising from thousands of political and military events and real world operations during the 1990s, PfP stands alone as the principle NATO means of 
multilateral security cooperation in Eurasia. PfP provides a unique set of tools for NATO and non-NATO policy-makers, planners and operators to tackle together the challenges of the twenty-first century.

As the PfP process gains greater acceptance in Eurasia, NATO appears destined for unforeseen, although not surprising, further evolution. ${ }^{35}$ Indeed, NATO's 1999 New Strategic Concept established the basic framework for a broader concept of NATO's twenty-first-century mission. The 1999 Strategic Concept provides PfP states with the ability to consult, cooperate and coordinate during crises, and to operate with NATO forces in a variety of contingencies. Although the NATO outreach to Eurasian nations cannot begin to solve all of the region's security challenges, PfP has served as a crucial baseline from which to forge the political and military ties needed for the United States and its allies to establish and maintain an effective international coalition against global terrorism.

More lessons can eventually be learned about how well policy-makers, planners and operators functioned in and around PfP countries surrounding Afghanistan as well as in the Caucasus and in Southeastern Europe. As a region long left out of Euro-Atlantic security calculations, the Eurasian area conceivably will represent a more important geostrategic space for the major world powers. Whether interests lie in access to natural resources, environmental challenges, or multilateral efforts to combat international terrorism, the Eurasian area is destined to become increasingly important to NATO's operational interests. PfP's pragmatic and realistic mechanisms provide the needed foundation from which a far different type of international coalition can confront non-traditional security challenges. Ultimately, the PfP's future success will depend on its resource requirements and NATO member resource investment. With an adequate degree of NATO attention, progress can be sustained towards enabling international coalitions of the present and future to launch operations - counter-terrorist and otherwise - based on lessons learned and training areas provided. As NATO's most important member, the United States must figure prominently, however, in this multilateral cooperative security process if PfP is to survive. Moreover, the United States, its NATO allies and PfP partners together must reshape NATO to deal more effectively with training, planning and operating to counter the twenty-first-century challenges of terrorism, WMD proliferation, ethnic conflict and narcotics trafficking. ${ }^{36}$

Countering the original criticism that NATO's PfP project signalled western hesitation and lack of resolve on NATO enlargement in the early 1990s, PfP now provides the key operational planning tools for multilateral security cooperation in Eurasia. PfP remains the only proactive multilateral, cooperative and political/military institutional procedure for NATO and Eurasia to test, modify and develop current and future plans for joint efforts at combating the non-traditional security challenges in the region. The initial American unilateralism in its war on terrorism and its policies 
towards 'rogue' states have no doubt increased transatlantic tensions more than the regional problems of Eurasia. As a result, the means for ensuring the preservation of the NATO and PfP regional Eurasian cooperation requires a consensus - particularly between Americans and Europeans - on their interests inside and outside of Europe. In the absence of such a consensus, it will become increasingly difficult to coordinate the effective planning of future operations out of area. If a consensus can be reached and sustained, then troop deployments will occur multilaterally, or US planners will synchronise their much more powerful and rapidly deployable US troop contingents for phased multilateral PfP operations after first-stage deployments. The question remains of whether NATO itself can adequately adapt to the dramatically changed twenty-first-century security environment by going sufficiently beyond its core Altantic orientation.

\section{Notes}

1 For example: S. Frederick Starr, 'Making Eurasia Stable', Foreign Affairs, 75:1 (1996), pp. 80-92; Strobe Talbott, 'A Farewell to Flashman: American Policy in the Caucasus and Central Asia', address at the Johns Hopkins School of Advanced International Studies, Washington, DC, U.S. Department of State Dispatch, 8:7 (1997), pp. 10-13; Glen E. Howard, 'NATO and the Caucasus: The Caspian Axis', in Stephen Blank (ed.), NATO After Enlargement: New Challenges, New Missions, New Forces (Carlisle Barracks, PA: Strategic Studies Institute, US Army War College, 1998), pp. 151-228; Rachel Bronson, 'NATO's Expanding Presence in the Caucasus and Central Asia', in Blank, NATO After Enlargement pp. 229-54; Robin Bhatty and Rachel Bronson, 'NATO's Mixed Signals in the Caucasus and Central Asia', Survival, 42:3 (2000), pp. 129-45; Anatol Lieven, 'The Caucasus and Central Asia Ten Years After the Soviet Collapse', eurasianet.org (21 August 2001); and Pauline Jones Luong and Erika Weinthal, 'New Friends, New Fears in Central Asia', Foreign Affairs, 81:2 (2002), pp. 61-70.

2 For early overviews of cooperative security and PfP, their conceptualisation and impact, see James M. Goldgeier and Michael McFaul, 'A Tale of Two Worlds: Core and Periphery in the Post-Cold War Era', International Organization, 46:2 (1992), pp. 467-91; Ashton B. Carter, William J. Perry and John D. Steinbruner, A New Concept of Cooperative Security (Washington, DC: Brookings Institution, 1992); Janne E. Nolan (ed.), Global Engagement: Cooperation and Security in the 21st Century (Washington, DC: Brookings Institution, 1994); and 'Partnership for Peace: Invitation', NATO Ministerial Communiqué M-1(94)2, issued by the heads of state and government participating in the meeting of the North Atlantic Council, 10 January 1994.

3 Sean Kay and Joshua Spero, 'Keep NATO Relevant for 21st Century', Defense News (17-23 December 2001), p. 27.

4 Officials giving the PfP process high priority included the secretary of defence, William Perry, and his key assistant secretaries, among them Joseph Nye, Ashton Carter and Franklin Kramer. Also supportive were the secretary of state, Warren Christopher, and his deputy, Strobe Talbott, along with the assistant secretary of 
state for Europe and Canada, Richard Holbrooke. The national security advisor, Anthony Lake, the joint chiefs' strategic plans and policy director, Army Lieutenant-General Wesley Clark, Army Lieutenant-General Daniel Christman and Air Force Lieutenant-General Richard Myers also provided key support for the PfP.

5 As the senior civilian strategic planner, the author shaped the heart of the PfP evolution, developing, operationalising and implementing its many intricate and multilateral cooperative initiatives and enhancements in Europe and Eurasia from 1994 to 2000 in the Joint Chiefs of Staff's Directorate for Strategic Plans and Policy. For published accounts of the phases of the US and PfP processes, see Catherine M. Kelleher, The Future of European Security: An Interim Assessment (Washington, DC: Brookings Institution, 1995), pp. 67-105; Sean Kay, NATO and the Future of European Security (Lanham, MD: Rowman and Littlefield, 1998), pp. 61-87; James M. Goldgeier, Not Whether But When: The U.S. Decision to Enlarge NATO (Washington, DC: Brookings Institution, 1999), pp. 14-44; and David S. Yost, NATO Transformed: The Alliance's New Roles in International Security (Washington, DC: US Institute of Peace Press, 1998), pp. 97-187.

6 Stephen Blank, U.S. Military Engagement with Transcaucasia and Central Asia (Carlisle Barracks, PA: U.S. Army War College, Strategic Studies Institute, June 2000), pp. 14-16.

7 These two states also became members of the PfP and this relationship served as the foundation for their broader relationships with NATO via a NATO-Russia council and a NATO-Ukraine special relationship.

8 Impressions by the author and U.S. Annual Report to Congress on the Partnership For Peace, jointly prepared by the State Department and the Defense Department, pursuant to section 514 of the Foreign Relations Authorization Acts, Fiscal Years 1994-2002.

9 Randall L. Schweller, 'Bandwagoning for Profit: Bringing the Revisionist State Back In', International Security, 19:1 (1994), pp. 72-107, esp. pp. 74-5; Randall L. Schweller, Deadly Imbalances: Tripolarity and Hitler's Strategy of World Conquest (New York: Columbia University Press, 1998), pp. 76-7; and Kenneth N. Waltz, Theory of International Politics (New York: Random House, 1978), p. 126.

10 Schweller, 'Bandwagoning for Profit', pp. 104-7.

11 Glenn H. Snyder, 'Alliances, Balance and Stability', International Organization, 45:1 (1991), pp. 121-42, esp. p. 128.

12 Andrew Kydd, 'Sheep in Sheep's Clothing: Why Security Seekers Do Not Fight Each Other', Security Studies, 7:1 (1997), pp. 114-55, esp. p. 152; and Andrew Kydd, 'Trust, Reassurance, and Cooperation', International Organization, 54:2 (2000), pp. 325-57, esp. pp. 325-7.

13 For example, see Charles L. Glaser, 'Realists as Optimists: Cooperation as Self-Help', in Michael E. Brown et al. (eds), Theories of War and Peace: An International Security Reader (Cambridge, MA: MIT Press, 1998); Jeffrey W. Taliaferro, 'Security Seeking under Anarchy: Defensive Realism Revisited', International Security, 25:3 (2000/01), pp. 128-61, esp. p. 159; and Gideon Rose, 'Neoclassical Realism and Theories of Foreign Policy', World Politics, 51:1 (1998), pp. 144-72.

14 Mark Kramer, 'Neorealism, Nuclear Proliferation, and East-Central European Strategies', in Ethan B. Kapstein and Michael Mastanduno (eds), Unipolar Politics: Realism and State Strategies After the Cold War (New York: Columbia University 
Press, 1999), pp. 428, 437-8, 462.

15 For a survey of assessments of the PfP, see Henry Kissinger, Diplomacy (New York: Simon and Schuster, 1994), pp. 824-6; Charles Kupchan, 'Strategic Visions', World Policy Journal, 11:1 (1994), pp. 112-22; Nick Williams, 'Partnership for Peace: Permanent Fixture or Declining Asset?', in Philip H. Gordon (ed.), NATO's Transformation: The Changing Shape of the Atlantic Alliance (Lanham, MD: Rowman and Littlefield, 1997), pp. 221-33; Daniel N. Nelson, 'Post-Communist Insecurity', Problems of Post-Communism, 47:5 (2000), pp. 31-7; Sean Kay, 'NATO's Open Door: Geostrategic Priorities and the Impact of the European Union', Security Dialogue, 32:2 (2001), pp. 201-16; and 'Peacekeeping and War: No, they're Not Incompatible', The Economist (16 August 2001).

16 See Michael Loriaux, 'Realism and Reconciliation: France, Germany, and the European Union', in Kapstein and Mastanduno, Unipolar Politics, pp. 378-9; and Joshua B. Spero, 'Enhancing Great Powers: Medium Size State Impact on Regional Security Cooperation', manuscript.

17 For general discussion of NATO's post-Cold War transition see Kelleher, Future of European Security; Robert McCalla, 'NATO's Persistence after the Cold War', International Organization, 50:3 (1996), pp. 445-75; Kay, NATO and the Future of European Security; Yost, NATO Transformed; and Celeste A. Wallander, 'Institutional Assets and Adaptability: NATO after the Cold War', International Organization, 54:4 (2000), pp. 705-36, esp. pp. 721-3, 728-31.

18 US Department of Defense, United States Security Strategy for Europe and NATO (Washington, DC: GPO, 1995); and US Department of Defense, Partnership for Peace (Washington, DC: GPO, 1996).

19 Vladimir Socor, 'Major NATO Exercise Successfully Held in Georgia', Jamestown Foundation, Monitor (26 June 2001), available from NEDB@Latvia-USA.org.

20 Transcript of interview by General John M. Shalikashvili, chairman, joint chiefs of staff, with reporters from the International Herald Tribune, USA Today, Defense News, and Jane's Defense News (16 June 1997); and 'Partnership for Peace: An Enhanced and More Operational Partnership', NATO Fact Sheets (6 September 2000), available from www.nato.int/docu/facts/2000/PfP-enh.htm.

21 For NATO's current strategy and rationale for twenty-first-century missions, see The Alliance's Strategic Concept, approved by the heads of state and government participating in the meeting of the North Atlantic Council in Washington DC, 23 and 24 April 1999, NATO Press Release NAC-S(99)65 (24 April 1999), available from www.nato.int/docu/pr/1999/p99-065e.htm.

22 For background, see S. Frederick Starr (ed.), The Legacy of History in Russia and the New States of Eurasia (Armonk, NY: M. E. Sharpe, 1994); Zbigniew Brzezinski, The Grand Chessboard: American Primacy and its Geostrategic Imperatives (New York: Basic Books, 1997), pp. 123-50; Rosemarie Forsythe, 'The Politics of Oil in the Caucasus and Central Asia', Adelphi Paper 300 (Oxford: Oxford University Press for the International Institute for Strategic Studies, 1996); Pavel Baev, Russia's Policies in the Caucasus (London: The Royal Institute of International Affairs, 1997); and Jan H. Kalicki, 'Caspian Energy at the Crossroads', Foreign Affairs, 80:5 (2001), pp. 120-35.

23 Joel E. Williamson and Jennifer D. P. Moroney, 'Security Cooperation Pays Off: A Lesson from the Afghan War', Current Defense Analyses, (2002), pp. 1-3.

24 Vladimir Socor, 'War Draws Central Asia’s “Stans” Closer to the U.S.', Wall Street 
Journal Europe (18 January 2002), available from Johnson's Russia List No. 6029, davidjohnson@erols.com; Todd S. Purdum, 'The Allies: Uzbekistan's Leader Doubts Chances for Afghan Peace', New York Times (14 March 2002); and Armen Khanbabyan, 'Georgia is Only the Beginning: The American Presence in the Transcaucasus Will Quickly Expand', Nezavisimaya Gazeta (14 March 2002), available from Johnson's Russia List No.6136, davidjohnson@erols.com.

25 Sunanda K. Datta-Ray, 'A Central Asian Initiative that Could Eliminate bin Laden', International Herald Tribune (20 September, 2001).

26 See Bhatty and Bronson, 'NATO's Mixed Signals', pp. 131-8.

27 'Turkey Might Get Two Azeri Military Airports', BBC Monitoring/Azerbaijani TV station ANS (9 January 2002), NEDB, available from NEDB@Latvia-USA.org; Eric S. Margolis, 'Russia Checkmated its New Best Friend', Los Angeles Times (28 November 2001); and Patrick E. Tyler, 'The Morning After Dawns on Moscow', New York Times (16 December 2001).

28 See, for example, U.S. Annual Report to Congress on the Partnership For Peace (2002); and Bruce Pannier, 'Central Asia: Ten Years After', Radio Free EuropeRadio Liberty, Johnson's Russia List, No. 5436 (11 September 2001), available from davidjohnson@erols.com.

29 See the draft text (October 2001) of the 'Multilateral Agreement on Transit of Goods Subject to Export Controls', arranged by the US Department of State. According to this, the governments of the Republic of Armenia, the Azerbaijan Republic, Georgia, the Republic of Kazakhstan, the Kyrgyz Republic, the Republic of Tajikistan, and the Republic of Uzbekistan will be guided by the Treaty on NonProliferation of Nuclear Weapons, the Convention on Banning Chemical Weapons and the Convention on Banning Bacteriological Weapons, aimed at facilitating the transit of goods subject to export controls and preventing unauthorised transit, thus enabling them to strengthen national, regional and international security, and expanding economic ties, transshipments and international trade.

30 Michael R. Gordon with C. J. Chivers, 'U.S. May Gain Use of More Air Bases to Strike Taliban', New York Times (5 November 2001); Ariel Cohen, 'Moscow, Washington and Tbilisi Wrestle with Instability in the Pankisi Gorge', New York Times (19 February 2002); 'NATO Backs Anti-Terror Operation in Pankisi Gorge', Interfax (8 March 2002), available from NEDB@Latvia-USA.org; and David Fillipov, 'US Troops Help Ex-Soviet State fight Militants', Boston Globe (19 March 2002), available from Johnson's Russia List No.6143, davidjohnson@erols.com.

31 Phase I of RAI is a study of PfP nation requirements to build and operate an effective air sovereignty system. Phase II is implementation of the study results by the PfP nation. Equipment purchases between US and PfP nations depend partially on PfP funds to build Air Sovereignty Operations Centres (ASOCs), or command and control centres in each country as the PfP states integrate the ASOCs.

32 Report to Congress on the Partnership for Peace: Developments through July 15, 2001, pursuant to section 514 of the Foreign Relations Authorization Act, Fiscal Years 1994-1995 (P.L. 103-236) and section 205 of the NATO Participation Act of 1994 (Title II of P.L. 103-447), pp. 27-9.

33 Report to Congress on the Partnership for Peace: Developments through July 15, 2001, pp. 15-17. Another important bilateral 'in the spirit' of PfP exercise, namely Peaceful Star 2001, sponsored by Turkey, builds on the US bilateral 
series in the Caucasus and Central Asia and involves nearly all the seven Eurasian states in conducting field training based on pooling PfP experiences from the NATO-led operations in Bosnia. 'Peaceful Star-2001 Exercises Begin in Istanbul', Turkish News Agency, Anatolia/BBC monitoring (19 September 2001), available from NEDB@Latvia-USA.org.

34 'NATO Command and Staff Exercises Begin In Baku', Interfax (5 November 2001), available from NEDB@Latvia-USA.org.

35 Alliance's Strategic Concept.

36 For overcoming the declining policy and resource commitment to PfP within the context of NATO-EU relations, see Kay, 'NATO's Open Door'; and Kay and Spero, 'Keep NATO Relevant'. 